\title{
Analisis Bibliometrik dari Penelitian Geologi untuk Tata Guna Lahan Perkotaan: 1950-2019
}

\author{
Yuniarti Ulfa ${ }^{1,2, a)}$, Dasapta Erwin Irawan ${ }^{1, b)}$, B. Kombaitan ${ }^{3, c)}$ dan Deny \\ Juanda Puradimaja ${ }^{1, d)}$
}

\author{
${ }^{1}$ Kelompok Keahlian Geologi Terapan, \\ Fakultas Ilmu dan Teknologi Kebumian, Institut Teknologi Bandung, \\ Jl. Ganesha no. 10 Bandung, Indonesia, 40132 \\ ${ }^{2}$ Program Studi Teknologi Geologi Terapan \\ Politeknik Geologi dan Pertambangan "AGP" \\ Jl. Cisaranten Kulon no. 40 Bandung, Indonesia, 40293
}

${ }^{3}$ Kelompo' Keahlian Pengelolaan Pembangunan dan Pengembangan Kebijakan

ekr ah Arsitektur, Perencanaan dan Pengembangan Kebijakan,

万 Jl. Ganesha no. 10 Bandung, Indonesia, 40132

a) yınia.ti.ulfa@students.itb.ac.id (corresponding author)

b) erwin@fitb.itb.ac.id

c) benk@pl.itb.ac.id

d)dny juanda@gl.itb.ac.id

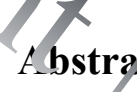

Sejak dipopulerkan oleh F. Stuart Chapin Jr pada tahun 957 onsep tata guna lahan perkotaan sudah menyinggung unsur-unsur terkait geologi. Meningkatnya jumlan pe lan duk dunia yang tinggal di perkotaan pun menjadikan geologi makin dibutuhkan untuk memastikan ko a ang berkelanjutan. Penelitian ini dilakukan untuk mengetahui bagaimana geologi telah dimanfaatkan unt ik at guna lahan perkotaan. Artikel ilmiah yang relevan dalam jurnal dan prosiding terindeks Scopus (1950-2110 dianalisis dengan metode tinjauan pustaka sistematis (SLR). Parameter yang dianalisis meliputi aspek ju. lah Texbitan, pilihan jurnal, ketokohan penulis, asal negara dan institusi penulis, sub-topik pembahasan, kata hunci don jumlah kutipan. Hasil analisa selanjutnya dipetakan dengan aplikasi VOSviewer. Total 216 artikel ilmar ya g-velevan telah diidentifikasi, dan hasilnya telah mampu menjawab negara dan institusi mana saja li uur a yang intens meneliti aplikasi geologi untuk tata guna lahan perkotaan. Publikasi terkait juga cenderung mengalami peningkatan signifikan pada kurun waktu tahun 2002 hingga 2013. Topik populer penelitian adalah tentang mengukur potensi bahaya dan kerentanan suatu wilayah dari potensi tanah longsor, amblesan (di zona karst), kekeringan, banjir dan gempabumi di Kawasan Perkotaan berbasis metode GIS dan AHP.

Kata-kata kunci: Geologi perkotaan, Tinjauan pustaka sistematis, Tata guna lahan,

\section{PENDAHULUAN}

Teori yang pertama kali menjelaskan pola tata guna lahan di perkotaan diungkapkan oleh Ernest Burgess di tahun 1923. Burgess mengungkapkan bahwa sebuah kota berkembang dari satu titik pusat menuju serangkaian zona konsentris [1,2]. Teori ini disempurnakan oleh Homer Hoyt di tahun 1933 serta Harris dan Ullman di tahun 1945 bahwa perkembangan kota tidak semestinya konsentris, tetapi mengikuti sektor-sektor tertentu sehingga terbentuk beberapa titik pusat perkotaan [2]. Meningkatnya fenomena urbanisasi terutama 
di negara-negara berkembang membawa tantangan besar bagi kawasan perkotaan akibat adanya desakan kebutuhan pada sumber daya alam, ruang dan pelayanan [3,4]. Sehingga F. Stuart Chapin Jr. merumuskan aspek-aspek penentu proses urbanisasi dan pola penggunaan lahan yaitu (i) aspek ekonomi; (ii) sosial; dan (iii) kepentingan publik [2]. Khusus aspek kepentingan publik adalah segala sesuatu yang menyangkut lingkungan fisik yang mampu memberikan kepuasan bagi warganya (livability), salah satunya yaitu aman dari potensi bahaya (geologi) seperti banjir. Yang juga disinggung terkait geologi untuk perencanaan tata guna lahan perkotaan adalah penyiapan berbagai peta dasar fisik lahan berdasarkan data fisiografi (topografi), data potensi hidrologi serta banjir, dan data struktur geologi, seperti pada gambar 1 .

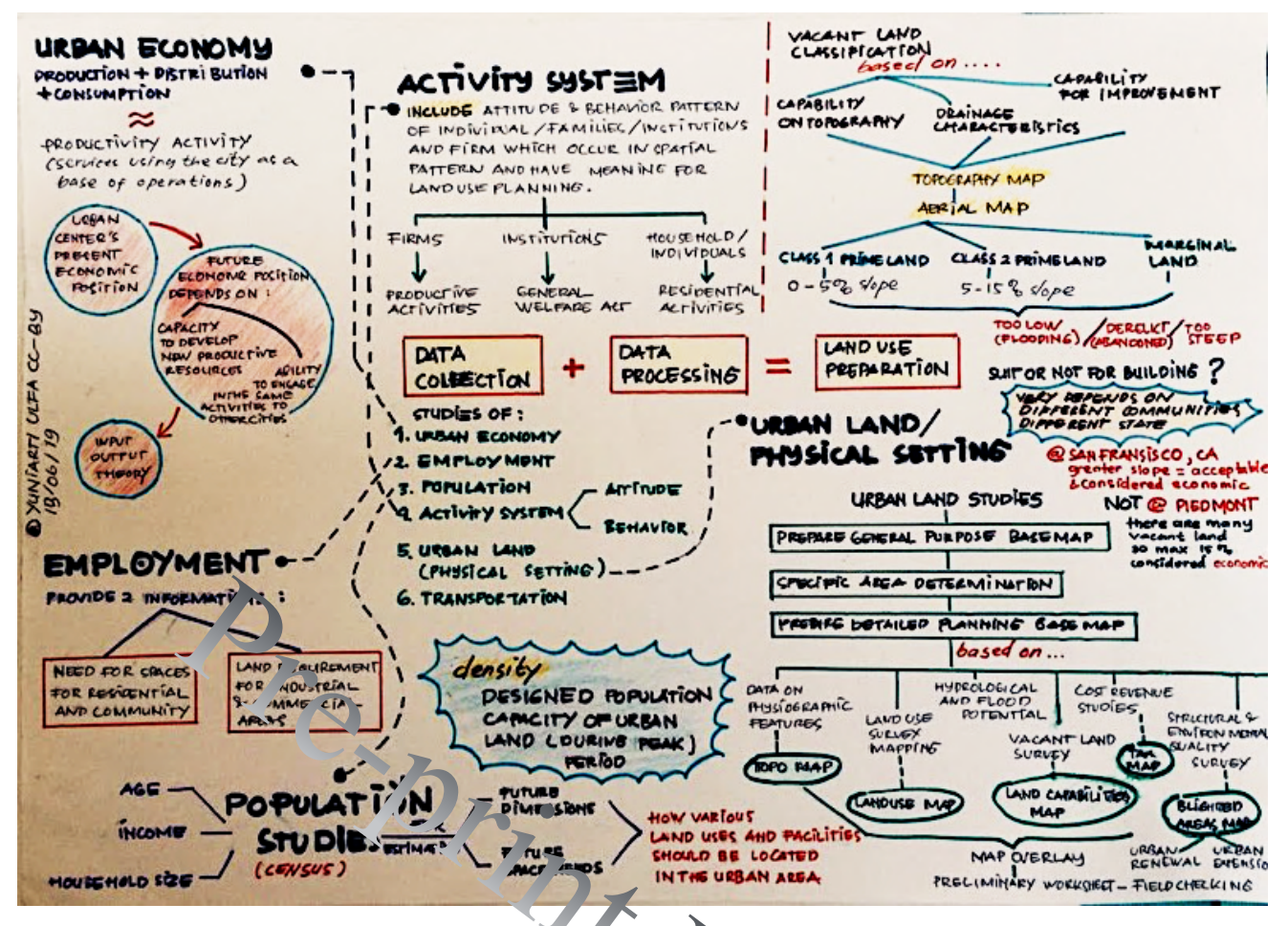

Gambar 1. Enam aspek data yang perlu dikaji dalam me tyiapka penggunaan lahan (ekonomi, ketenagakerjaan, populasi penduduk, perilaku manusia, kondisi fisik lahan, dan transpor as ). Terkait data geologi banyak termasuk ke dalam aspek kondisi fisik lahan sebagaim na dingkas dari [2].

Kini lebih dari 50\% penduduk dunia hidup di Kawasan perkotaa [ / b hkan diprediksi mencapai angka hampir 70\% di tahun 2030 [5], membuat geologi makin dibutuhk in mituk memastikan kota yang berkelanjutan [6], tidak lagi sekedar seperti yang digambarkan oleh F. Stuai chapin di atas. Penelitian ini dilakukan untuk manjawab pertanyaan penelitian, "Bagaimana geologi telah cima" factkan untuk tata guna lahan perkotaan berdasarkan tinjauan pustaka sistematis (SLR) dari 216 artikel ilmiah cri deks Scopus yang terbit antara periode 1950 dan 2019?".

Tinjauan pustaka sistematis (Systematic Literature Review - SLR) adalah metode stu a pustaka yang mengidentifikasi, menilai, dan menginterpretasi seluruh temuan-temuan pada suatu topik penelitian, untuk menjawab pertanyaan penelitian yang telah ditetapkan sebelumnya. Kelebihan SLR yaitu efektif, komprehensif, obyektif, terbuka, baku, dan metode ini dapat diulang oleh siapapun [7,8]. SLR sangat baik dilakukan (i) sebelum memulai penelitian baru; (ii) untuk mempelajari penelitian sebelumnya; (iii) untuk mengetahui kecenderungan penelitian dunia dalam sebuah topik tertentu; (iv) untuk mengidentifikasi penelitian-penelitian lain yang serupa dalam topik tersebut; dan (v) untuk memastikan kebaruan dari sebuah potensi penelitian baru [8]. Akhirnya, sebagai bagian dari studi program doktoral di bidang geologi perkotaan, penelitian ini diharapkan mampu mengidentifikasi potensi kebaruan penelitian-penelitian yang akan datang di bidang ini. 
Tabel 1. Tahapan penentuan kriteria pencarian berbasis data SCOPUS

\begin{tabular}{|c|c|c|c|c|}
\hline Tahap & $\begin{array}{l}\text { Penyertaan/ } \\
\text { pengecualian }\end{array}$ & Deskripsi & Kriteria pencarian & Hasil \\
\hline Ke-satu & $\begin{array}{l}\text { Kriteria } \\
\text { pencarian }\end{array}$ & Kata kunci & $\begin{array}{l}\text { (TITLE-ABS-KEY (urban OR city AND "land use" } \\
\text { AND planning)) AND (TITLE-ABS-KEY (geolog*)) }\end{array}$ & 566 \\
\hline \multirow[t]{3}{*}{ Ke-dua } & $\begin{array}{l}\text { Penyertaan } \\
\text { berdasarkan } \\
\text { jenis artikel } \\
\text { ilmiah }\end{array}$ & $\begin{array}{l}\text { Hanya } \\
\text { menyertakan } \\
\text { artikel dari } \\
\text { jurnal dan } \\
\text { prosiding }\end{array}$ & $\begin{array}{l}\text { AND (LIMIT-TO (DOCTYPE, “ar”) OR (LIMIT-TO } \\
\text { (DOCTYPE, “cp”)) }\end{array}$ & 525 \\
\hline & $\begin{array}{l}\text { Penyertaan dan } \\
\text { pengecualian } \\
\text { berdasarkan } \\
\text { bahasa }\end{array}$ & $\begin{array}{l}\text { Hanya artikel } \\
\text { ilmiah } \\
\text { be oal asa } \\
\text { disert yan. } \\
\text { Artikel d that } \\
\text { Bahasa suain } \\
\text { Bahasa Inggris } \\
\text { dikecualikan }\end{array}$ & $\begin{array}{l}\text { AND (LIMIT-TO (LANGUAGE, “English")) AND } \\
\text { (EXCLUDE (LANGUAGE, "French") OR EXCLUDE } \\
\text { (LANGUAGE, "German") OR EXCLUDE } \\
\text { (LANGUAGE, "Italian") OR EXCLUDE (LANGUAGE, } \\
\text { "Spanish")) }\end{array}$ & 444 \\
\hline & $\begin{array}{l}\text { Pengecualian } \\
\text { berdasarkan } \\
\text { bidang studi }\end{array}$ & $\begin{array}{l}\text { Artikel dengan } \\
\text { bidang studi } \\
\text { tidak terkait } \\
\text { dikecualikan }\end{array}$ & 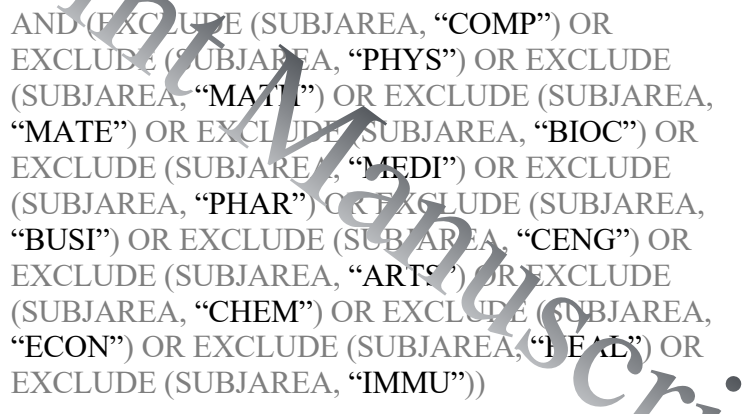 & 376 \\
\hline Ke-tiga & $\begin{array}{l}\text { Pengecualian } \\
\text { berdasarkan } \\
\text { abstrak dan kata } \\
\text { kunci }\end{array}$ & $\begin{array}{l}\text { Artikel dengan } \\
\text { abstrak dan kata } \\
\text { kunci yang tidak } \\
\text { terkait } \\
\text { dikecualikan }\end{array}$ & $\begin{array}{l}\text { Data diunduh dalam format CSV dan PDF } \\
\text { Abstrak dibaca satu persatu untuk memastikan isi } \\
\text { publikasi sesuai dengan kriteria pencarian. }\end{array}$ & \\
\hline
\end{tabular}

\section{METODOLOGI}

Dalam makalah ini, metode tinjauan pustaka terdiri dari dua langkah, yaitu: (1) pemilahan artikel ilmiah yang relevan, dan (2) analisis artikel.

\section{Pemilahan artikel ilmiah yang relevan}

Penulis mengumpulkan publikasi penelitian yang diterbitkan dari tahun 1950 hingga 2019 menggunakan fasilitas mesin pencari Scopus pada 17 Juni 2019. Pemilihan tahun 1950 sebagai rentang awal, disebabkan teori tata guna lahan perkotaan yang mulai memuat unsur-unsur geologi, disusun oleh F. Stuart Chapin Jr pada tahun 1957.

Langkah pertama sebagaimana dirangkum dalam tabel 1, pada tahap ke-satu, penulis membatasi kriteria kata kunci yaitu urban atau city "land use" planning dan geology. Terpilih 566 artikel terindeks Scopus. Tahap ke-dua, memilah dari 566 artikel, berdasarkan penyertaan hanya artikel bersumber dari jurnal dan prosiding, sehingga terpilih 525 artikel diantaranya. Kemudian dipilah lagi berdasarkan bahasa yaitu hanya artikel ilmiah ber Bahasa Inggris yang disertakan. Artikel dalam bahasa selain Bahasa Inggris dikecualikan, 
sehingga tersisa 444 artikel diantaranya. Pemilahan berikutnya yaitu berdasarkan bidang studi, dimana artikel dengan bidang studi tidak terkait dikecualikan sehingga di tahap ke-dua tersaring 376 artikel. Adapun bidang studi yang dikecualikan adalah bidang computer, physics, mathematics, material, medical, pharmacy, business, chemical engineering, arts, chemistry, economics, health, dan immunology. Pada tahap ke-tiga, penulis mengimpor hasil tahap ke-dua ke dalam format CSV dan PDF. Abstrak, kata kunci penulis, kata kunci indeks, dan informasi kutipan 376 artikel ditinjau secara manual untuk menentukan pengecualian dari daftar. Akhirnya di langkah pertama, terpilih 216 artikel terindeks Scopus.

\section{Analisis artikel}

Langkah kedua adalah mengelompokkan 216 artikel terpilih di atas berdasarkan profil penulis, sub-topik pembahasan, kata kunci dan jumlah kutipan menggunakan perangkat lunak VOS viewer, termasuk untuk menghubungkan antar pengelompokkan tersebut. VOSviewer adalah perangkat lunak untuk membangun dan mem-visualisasikan jaringan bibliometrik [9]. Program ini dapat diakses secara tidak berbayar di www.vosviewer.com.

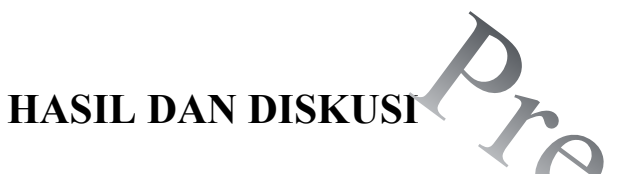

Jumlah artikel yang diterbitkan seti...pt thun

Meskipun rentang waktu pencarian ycng dit âpkan adalah tahun 1950-2019, namun hasil pencarian artikel penelitian geologi untuk tata guna lahan perk ta $\mathbf{A}$ yang ditemukan hanya berkisar antara tahun 1976 hingga 2019 (gambar 2). Total artikel yang ber (as 1 (identifikasi berjumlah 216 artikel, dengan kecenderungan peningkatan publikasi dari 2 di tahun 1096 med adi 14 di tahun 2018. Kecenderungan peningkatan tersebut paling terlihat antara tahun 2002 hingga 201/3.

Untuk penerbit, total 216 artikel di atas diterbitkan pada 100 ju nal yang berbeda antara tahun 1976-2019. Tabel 2 adalah daftar 10 jurnal yang paling banyak dipilih untuk mentu to ma geologi untuk tata guna lahan perkotaan antara tahun 1976-2019.

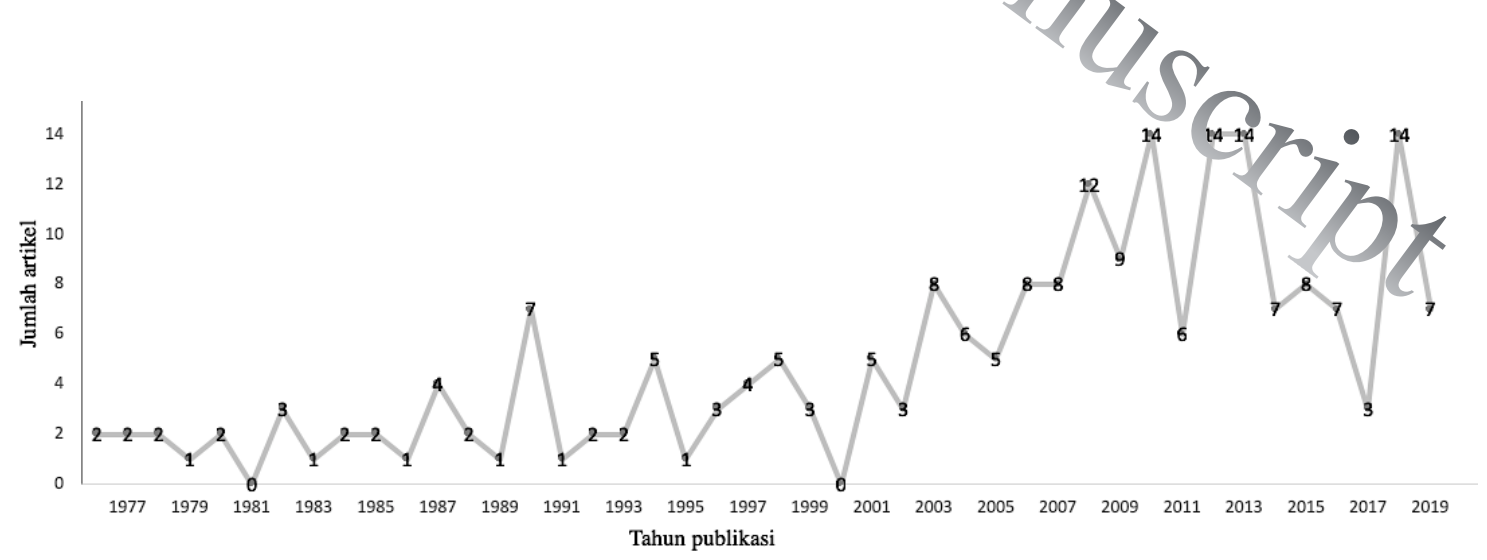

Gambar 2. Jumlah publikasi dari waktu ke waktu

\section{Kontribusi penulis}

Pada bagian ini akan membahas mengenai aspek ketokohan penulis, asal negara dan institusi penulis. Seperti pada tabel 3, para peneliti dari Amerika adalah yang paling banyak terlibat dalam penelitian geologi untuk tata guna lahan perkotaan, yaitu sebanyak 51 artikel, diikuti oleh penulis asal Cina yaitu sebanyak 26 artikel. Hal ini menunjukkan bahwa penelitian atau aplikasi geologi untuk tata guna lahan perkotaan menarik perhatian baik di negara maju maupun negara berkembang. Daftar negara-negara berikutnya mendukung fakta tersebut, bahwa baik negara maju maupun negara berkembang secara intensif melakukan penelitian di bidang ini. Visualisasi menggunakan aplikasi VOSviewer, turut mendukung data tersebut. Akan tetapi visual yang diperbesar menunjukkan bahwa peneliti dari institusi/ universitas di Amerika sedikit berkolaborasi dengan peneliti dari negara lain, dibandingkan dengan peneliti Cina yang banyak berkolaborasi dengan para peneliti dari Inggris (UK), Turki, Brazil, Mesir, Malaysia, Kanada, Norwegia dan Islandia (gambar 3). 
Tabel 2. Jurnal yang paling banyak dipilih untuk menerbitkan

\begin{tabular}{|c|c|c|}
\hline Jurnal & $n$ Artikel & IF \\
\hline Engineering Geology & 19 & 3.909 \\
\hline Environmental Earth Science & 9 & 1.871 \\
\hline Landscape and Urban Planning & 8 & 5.144 \\
\hline Environmental Monitoring and Assessment & 6 & 1.959 \\
\hline $\begin{array}{l}\text { Bulletin of Engineering Geology and the } \\
\text { Environment }\end{array}$ & 5 & 2.138 \\
\hline $\begin{array}{l}\text { Geological Society Engineering: } O \text { oplogy } \\
\text { Special Publication }\end{array}$ & 5 & 3.300 \\
\hline Natural Hazards & 3 & 2.319 \\
\hline Remote Sensing of Environment & & 8.218 \\
\hline Geomorphology & & \\
\hline $\begin{array}{l}\text { Environmental and Engineering } \\
\text { Geoscience }\end{array}$ & 3 & \\
\hline
\end{tabular}

Geology; Geotechnical Engineering and Engineering Geology

Geology; Earth Surface Processes; Soil Science, Environmental Chemistry; Pollution; Water Science and Technology; Global and Planetary Change

Nature and Landscape Conservation; Ecology; Management, Monitoring, Policy and Law General Environmental Science; Management, Monitoring, Policy and Law; Pollution

Geology; Geotechnical Engineering and Engineering Geology

Geotechnical Engineering and Engineering Geology

Water Science and Technology; Earth and Planetary Sciences (miscellaneous); Atmospheric Science

Geology; Soil Science; Computers in Earth Sciences

Earth-Surface Processes

Geotechnical Engineering and Engineering $G$ ology; Environmental Engineering; Earth and $P$ anetary Sciences (miscellaneous)

Tabel 3. Asal negara dan institusi penulis artikel geologi untuk tata guna ina potan yang diterbitkan

\begin{tabular}{|c|c|c|c|c|c|c|c|}
\hline & $\begin{array}{l}\text { Institusi/ } \\
\text { Universitas }\end{array}$ & Penulis & $n$ Artikel & & & Penulis & $n$ Artikel \\
\hline United States & 75 & 164 & 51 & Netherlands & 2 & & 2 \\
\hline China & 44 & 81 & 26 & Nigeria & 2 & & 2 \\
\hline United Kingdom & 16 & 41 & 16 & Poland & 4 & 5 & 2 \\
\hline India & 14 & 26 & 10 & Sweden & 9 & 12 & 2 \\
\hline Turkey & 14 & 36 & 10 & Switzerland & 5 & 7 & 2 \\
\hline Brazil & 12 & 30 & 8 & Thailand & 2 & 4 & 2 \\
\hline Australia & 4 & 17 & 7 & Andorra & 3 & 3 & 1 \\
\hline Finland & 6 & 18 & 6 & Belgium & 2 & 2 & 1 \\
\hline Greece & 9 & 18 & 6 & Cambodia & 1 & 1 & 1 \\
\hline Canada & 9 & 14 & 5 & Denmark & 2 & 3 & 1 \\
\hline Egypt & 8 & 12 & 5 & Ethiopia & 1 & 2 & 1 \\
\hline Italy & 12 & 24 & 5 & France & 5 & 13 & 1 \\
\hline Iran & 9 & 12 & 4 & Iceland & 3 & 3 & 1 \\
\hline Mexico & 6 & 16 & 4 & Jordan & 2 & 3 & 1 \\
\hline Norway & 11 & 13 & 4 & Madagascar & 2 & 2 & 1 \\
\hline Spain & 9 & 26 & 4 & Morocco & 1 & 4 & 1 \\
\hline Czech Republic & 2 & 9 & 3 & Philippines & 2 & 2 & 1 \\
\hline Germany & 7 & 8 & 3 & Russian & 4 & 4 & 1 \\
\hline Hong Kong & 7 & 10 & 3 & Serbia & 3 & 4 & 1 \\
\hline Japan & 5 & 6 & 3 & Singapore & 3 & 2 & 1 \\
\hline Malaysia & 2 & 13 & 3 & Slovakia & 2 & 5 & 1 \\
\hline Portugal & 9 & 12 & 3 & South Africa & 2 & 2 & 1 \\
\hline Saudi Arabia & 4 & 7 & 3 & South Korea & 2 & 3 & 1 \\
\hline Algeria & 4 & 8 & 2 & Taiwan & 3 & 6 & 1 \\
\hline Costa Rica & 4 & 8 & 2 & Tunisia & 2 & 3 & 1 \\
\hline Croatia & 4 & 4 & 2 & $U A E$ & 1 & 1 & 1 \\
\hline Indonesia & 2 & 3 & 2 & Zambia & 1 & 1 & 1 \\
\hline
\end{tabular}




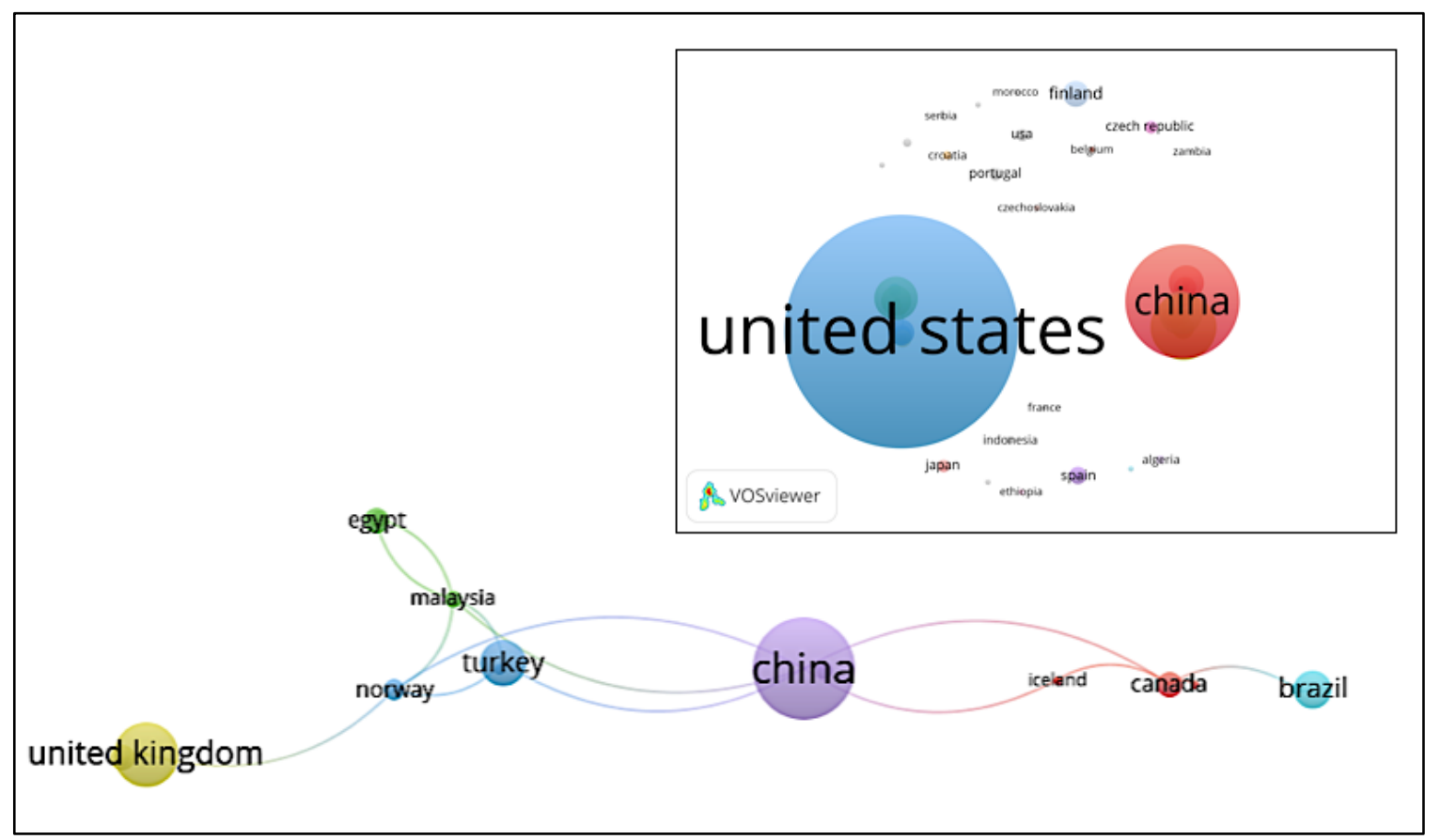

Gambar 3. Visualisasi dengan perangkat lunak VOSviewer yang memperlihatkan hubungan peneliti asal Cina dengan peneliti-peneliti dari negara lain dal $m$ kolaborasi penelitian geologi untuk tata guna lahan perkotaan. Sedangkan peneliti asal Amerika Serikat, mesk punnerupakan jumlah yang terbanyak, namun jarang berkolaborasi dengan peneliti dari negara-negara lain

Penulis asal Indonesia yang tercatat dal m jurnal terindeks Scopus, yang terlibat dalam penelitian geologi untuk tata guna lahan perkotaan ada $3 \mathrm{c}$ an yaitu B.I. Istijono dan B.I. Hakam dari Jurusan Teknik Sipil Universitas Andalas, Padang, Sumater . Bara Reduanya menulis artikel [25] pada tahun 2016. Satu lagi penulis yang tercatat adalah S. Suhari dari Dir kt ia Geologi Tata Lingkungan, Bandung yang menulis artikel [26] pada tahun 1993. Minimnya peneliti dar Ir donesia di bidang ini, karena dua sebab yaitu (i) penelitian di bidang geologi belum umum berintegrasi secara/hterdisipliner dengan penelitian bidang tata kota; (ii) mungkin ada banyak penelitian-penelitian sejenis dis bitkan di jurnal non-English karena rendahnya kemampuan literasi Bahasa Inggris para penelitinya, ma pun yang diterbitkan di jurnal ber-Bahasa Inggris namun tidak terindeks Scopus.

\section{Topik penelitian}

Berdasarkan kata kunci dari penulis, seperti dipetakan dalam aplikasi VOSviewer mer an ik an bahwa kata kunci yang paling populer dalam penelitian geologi untuk tata guna lahan perkot an drah GIS (Geographic Information System), diikuti oleh kata kunci geologi lingkungan (environmental geology), geologi teknik, urbanisasi, tata guna lahan, perencanaan perkotaan (urban planning) dan penginderaan jauh (remote sensing). Detail dari masing-masing kata kunci tersebut, terkait dengan kata-kata kunci yang lain (gambar 4a dan 4b).

Misalnya seperti di gambar 5, menunjukkan bahwa umumnya penelitian berbasis GIS untuk menilai kelayakan lahan (ketersediaan airtanah, kontaminasi airtanah), potensi bahaya geologi (amblesan, karst, erosi/abrasi air laut, tsunami), dan rekayasa keteknikan untuk pondasi (foundation engineering). Metode GIS seperti ditunjukkan pada gambar 5, umumnya dikolaborasikan dengan metode AHP (Analytic Hierarchy Process).

Kata kunci berikutnya yang mendominasi penelitian di tahun 2000-an adalah urbanisasi. Fenomena urbanisasi meningkatkan kebutuhan terhadap peta geologi. Penelitian berbasis peta geologi ini umumnya untuk menjamin kebutuhan air bersih penduduk serta menjamin keberlangsungan hidup manusia dari potensi sumber daya dan bahaya geologi pada pemukiman yang semakin merambah ke DAS (Daerah Aliran Sungai) atau watershed. Potensi bahaya banjir dan gempabumi (karena umumnya zona DAS merupakan zona lemah) adalah antara yang banyak diteliti. Model kasus penelitian yang paling banyak dirujuk adalah perencanaan perkotaan di California, Amerika Serikat (gambar 4b). 

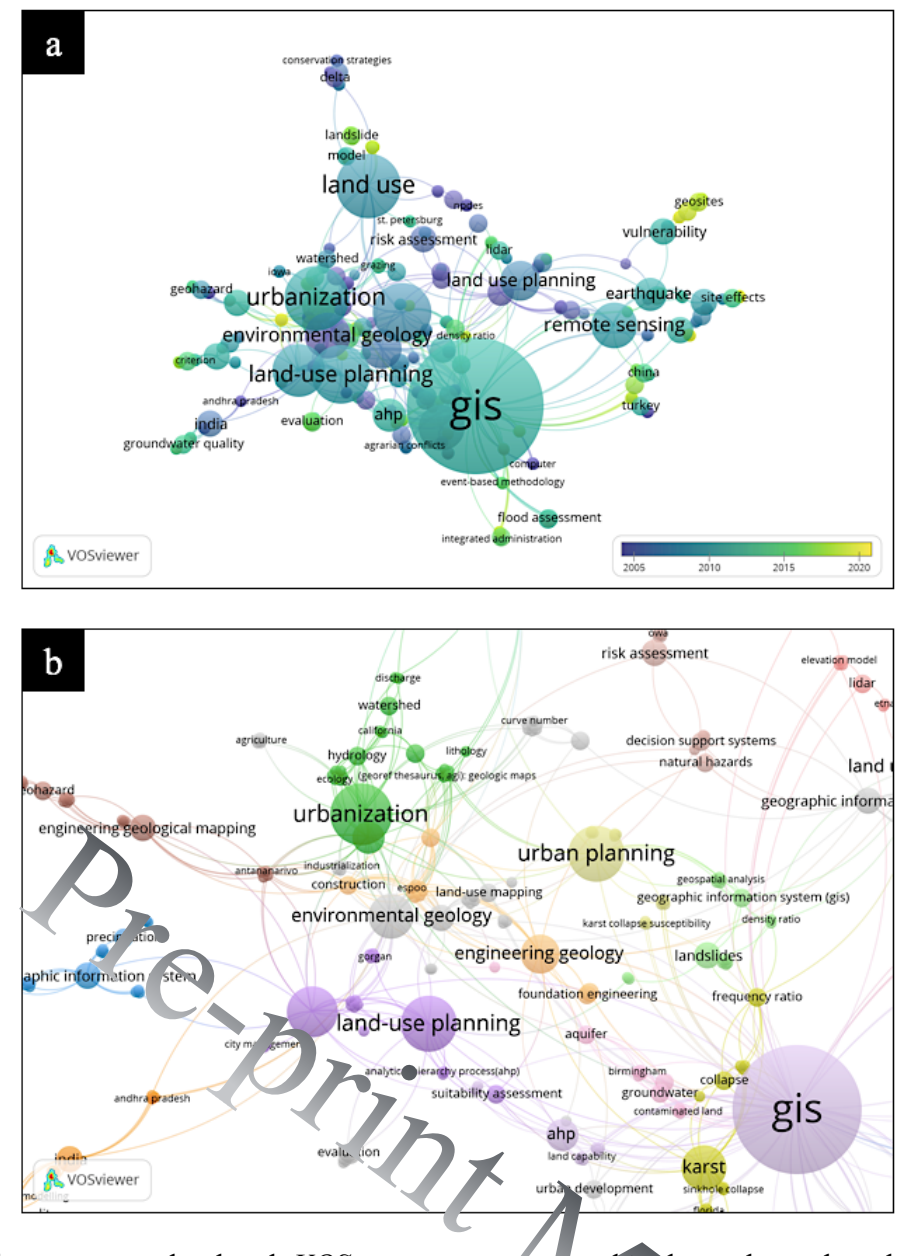

Gambar 4. Visualisasi dengan perangkat lunak VOSviewer yang nes ipert atkan sebaran kata-kata kunci penelitian yang populer antara tahun 1976-2019. (a) Nuansa warna hijau menunjukkan $c$ sminasi penelitian-penelitian tersebut pada tahun 2000-an. Sedangkan (b) adalah detail sub-topik dari kata-kata kunci tr-p puler tersebut, yaitu GIS (Geographic Information System), geologi lingkungan (environmental geology), geclo, te nik, urbanisasi, tata guna lahan, perencanaan perkotaan (urban planning) dan penginderaan $\mathrm{j}$. h $\mathrm{h}$ (en ote sensing).

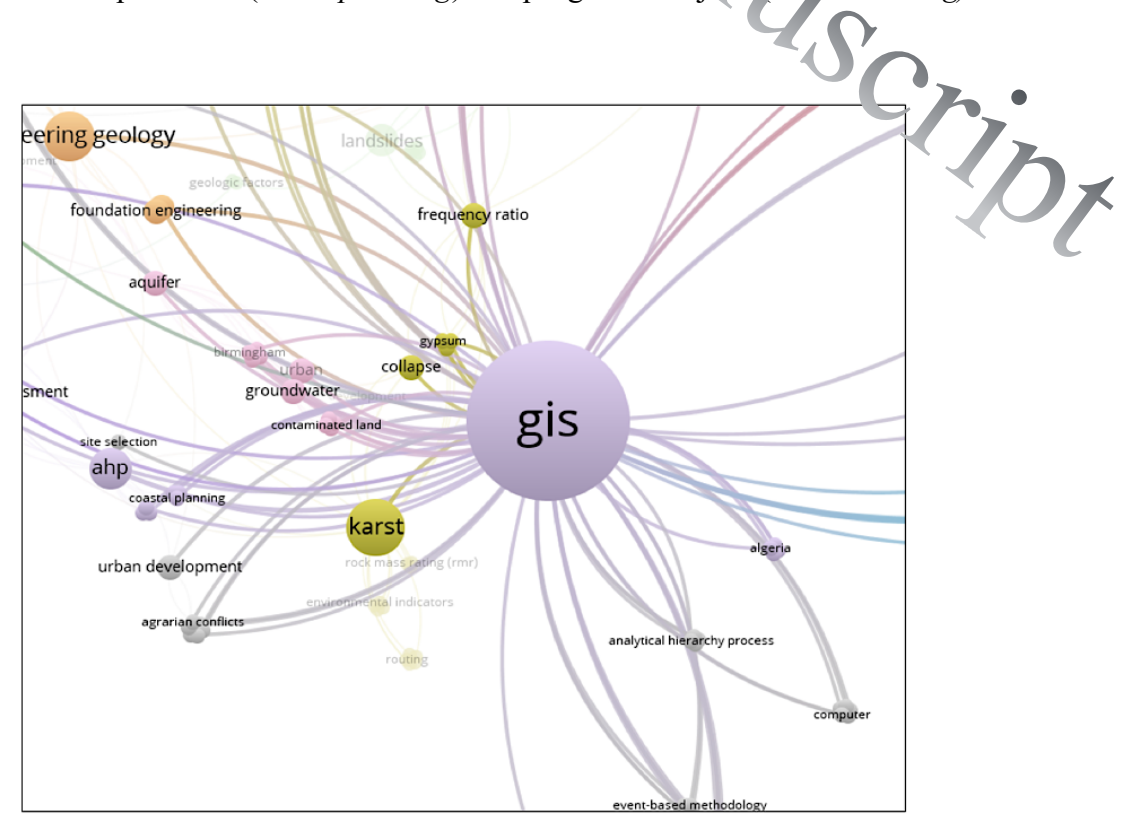

Gambar 5. Eksplorasi khusus untuk kata kunci GIS (Geographic Information System) 
Tabel 4. 15 Artikel yang paling banyak dikutip

\begin{tabular}{|c|c|c|}
\hline Penulis (tahun) & Judul artikel & $n$ Kutipan \\
\hline Van Westen et al. (2008) & $\begin{array}{l}\text { Spatial data for landslide susceptibility, hazard, and vulnerability } \\
\text { assessment: An overview [10] }\end{array}$ & 489 \\
\hline Yang et al. (2003) & $\begin{array}{l}\text { An approach for mapping large-area impervious surfaces: Synergistic } \\
\text { use of Landsat- } 7 \text { ETM }+ \text { and high spatial resolution imagery [11] }\end{array}$ & 331 \\
\hline Dai et al. (2001) & $\begin{array}{l}\text { GIS-based geo-environmental evaluation for urban land-use } \\
\text { planning: A case study [12] }\end{array}$ & 254 \\
\hline Wilson et al. (2003) & $\begin{array}{l}\text { Development of a geospatial model to quantify, describe and map } \\
\text { urban growth [13] }\end{array}$ & 185 \\
\hline Sutton (2003) & $\begin{array}{l}\text { A scale-adjusted measure of "urban sprawl" using night-time satellite } \\
\text { imagery [14] }\end{array}$ & 178 \\
\hline Henderson dan Xia (1997) & $\begin{array}{l}\text { SA applications in human settlement detection, population } \\
\text { estio ation and urban land use pattern analysis: a status report [15] }\end{array}$ & 149 \\
\hline Bledsoe dan Watson (2001) & Elfec of urbanization on channel instability [16] & 134 \\
\hline Bathrellos et al. (2012) & $\begin{array}{l}\text { Potential surat ity for urban planning and industry development } \\
\text { using natura } 1 \text { aaz d mapswand geological-geomorphological } \\
\text { parameters } 17]\end{array}$ & 133 \\
\hline Akbari et al. (2003) & $\begin{array}{l}\text { Analyzing the land cove of h } \mathrm{ban} \text { environment using high- } \\
\text { resolution orthophotos }[18]\end{array}$ & 131 \\
\hline Bryant (2006) & $\begin{array}{l}\text { Urban landscape conservation and the ole ecological greenways } \\
\text { at local and metropolitan scales [19] }\end{array}$ & 123 \\
\hline Mundia dan Aniya (2005) & $\begin{array}{l}\text { Analysis of land use/cover changes and urt in } x p \text { nsion of Nairobi } \\
\text { city using remote sensing and GIS [20] }\end{array}$ & 118 \\
\hline Tsihrintzis dan Hamid (1998) & $\begin{array}{l}\text { Runoff quality prediction from small urban catchmer s } \\
\text { SWMM [21] }\end{array}$ & 108 \\
\hline Huan et al. (2012) & $\begin{array}{l}\text { Assessment and validation of groundwater vulnerability to nit te } \\
\text { based on a modified DRASTIC model: A case study in Jilin City of } \\
\text { northeast China [22] }\end{array}$ & 6 \\
\hline Hürlimann et al. (2006) & $\begin{array}{l}\text { Detailed debris flow hazard assessment in Andorra: A } \\
\text { multidisciplinary approach [23] }\end{array}$ & 10 \\
\hline $\begin{array}{l}\text { Papadopoulou-Vrynioti et al. } \\
\text { (2013) }\end{array}$ & $\begin{array}{l}\text { Karst collapse susceptibility mapping considering peak ground } \\
\text { acceleration in a rapidly growing urban area [24] }\end{array}$ & 80 \\
\hline
\end{tabular}

Hasil ini diperkuat dengan daftar artikel yang paling banyak dikutip pada tabel 4. Kutipan terbanyak adalah pada artikel-artikel penelitian tentang mengukur potensi bahaya dan kerentanan suatu wilayah dari potensi tanah longsor, amblesan (di zona karst), kekeringan, banjir dan gempabumi. Institusi yang paling banyak melakukan penelitian-penelitian di atas tercatat adalah (i) Chinese Academy of Sciences; (ii) British Geological Survey; (iii) Colorado State University; (iv) Geologian Tutkemuskesus; dan (v) National and Kapodistrian University of Athens.

\section{KESIMPULAN}

Kecenderungan penelitian geologi untuk tata guna lahan perkotaan yang semakin meningkat setelah tahun 2000-an adalah untuk memastikan keberlangsungan kehidupan di suatu wilayah dari potensi bahaya dan sumber daya geologi, berbasis metode GIS dikombinasikan dengan AHP. Keterbatasan hanya artikel-artikel terindeks Scopus yang dianalisis, memungkinkan di luar topik tesebut, masih ada topik-topik populer lain yang juga sedang banyak diteliti. Kombinasi tinjauan pustaka sistematis (SLR) berbasis data dari Google Scholar dan ResearchGate perlu dilakukan di masa yang akan datang untuk melengkapi analisis bibliometrik pada penelitian geologi untuk tata guna lahan perkotaan. 


\section{UCAPAN TERIMA KASIH}

Penulis mengucapkan terima kasih kepada berbagai pihak yang telah membantu dalam penulisan artikel ini. Penelitian ini merupakan bagian dari tinjauan pustaka penulis dalam menyelesaikan studi program doktoral yang didanai oleh Beasiswa Pendidikan Indonesia-Reguler LPDP Kementrian Keuangan Indonesia dan Kelompok Keahlian Geologi Terapan FITB-Institut Teknologi Bandung.

\section{REFERENSI}

1. J. McDonagh, Theories of urban land use and their application to the Christchurch property market. Property and Land Economy Institute of New Zealand Newsletter (2007)

2. F. Stuart Chapin Jr., Urban land use planning $2^{\text {nd }}$ ed., Urbana University of Illinois Press (1965)

3. M. Criado, A. Martínez-Graña, F. Santos-Francés, S. Veleda, dan C. Zazo, Multi-Criteria Analyses of Urban Planning for City Expansion: A Case Study of Zamora, Spain. Sustainability, 9(10):1850 (2017)

4. F.M. Henderson dan Z.C.Y Ya, SAR applications in human settlement detection, population estimation and urban land use pr tern analysis: a status report. IEEE Trans. Geosci. Remote Sens., 35(1), 79-85 (1997)

5. P. Bolund dan S. Hunhamma, Ecosystem services in urban areas. Ecological economics, 29(2), 293301 (1999)

6. J.C. Gill, Geology and the sustainab de e e opment goals. Episodes, 40(1), 70-76 (2017)

7. R. Djalante, Research trends on hazards discters, risk reduction and climate change in Indonesia: a systematic literature review. Nat. Hazards E. ith sy t. Sci. 1-48, (2016).

8. K.M. Thomas, M.C. Georgios dan C.A. Dorde, in efficient framework for conducting systematic literature reviews in agricultural sciences. Science of the T/t tal Environment (2019)

9. N.J. Van Eck dan L. Waltman. Citation-based cluste'in of ublications using CitNetExplorer and VOSviewer. Scientometrics, 111(2), 1053-1070 (2017)

10. C.J. Van Westen, E. Castellanos, dan S.L. Kuriakose. Spatiai at fo landslide susceptibility, hazard, and vulnerability assessment: an overview. Engineering geology, $1 \mathrm{O}_{-}(3+)>112-131$ (2008)

11. L. Yang, C. Huang, C.G. Homer, B.K. Wylie, dan M.J. Coan. An upp oo $h$ for mapping large-area impervious surfaces: synergistic use of Landsat-7 ETM+ and high spatial esc ution imagery. Canadian journal of remote sensing, 29(2), 230-240 (2003)

12. F.C. Dai, C.F. Lee, dan X.H. Zhang. GIS-based geo-environmental evaluation f r harban land-use planning: a case study. Engineering geology, 61(4), 257-271 (2001)

13. E.H. Wilson, J.D. Hurd, D.L. Civco, M.P. Prisloe, dan C. Arnold. Development of a geos ati $r$ radel to quantify, describe and map urban growth. Remote sensing of environment, 86(3), 275-285 (20'3)

14. P.C. Sutton. A scale-adjusted measure of "urban sprawl" using night time satellite imagery. Remote sensing of environment, 86(3), 353-369 (2003)

15. F.M. Henderson dan Z.G. Xia. SAR applications in human settlement detection, population estimation and urban land use pattern analysis: a status report. IEEE transactions on geoscience and remote sensing, 35(1), 79-85 (1997)

16. B.P. Bledsoe dan C.C. Watson. Effects of urbanization on channel instability 1. JAWRA Journal of the American Water Resources Association, 37(2), 255-270 (2001)

17. G.D. Bathrellos, K. Gaki-Papanastassiou, H.D. Skilodimou, D. Papanastassiou, dan K.G. Chousianitis. Potential suitability for urban planning and industry development using natural hazard maps and geological-geomorphological parameters. Environmental earth sciences, 66(2), 537-548 (2012)

18. H. Akbari, L.S. Rose, dan H. Taha, H. Analyzing the land cover of an urban environment using highresolution orthophotos. Landscape and urban planning, 63(1), 1-14 (2003)

19. M.M. Bryant. Urban landscape conservation and the role of ecological greenways at local and metropolitan scales. Landscape and urban planning, 76(1-4), 23-44 (2006)

20. C.N. Mundia, dan M. Aniya. Analysis of land use/cover changes and urban expansion of Nairobi city using remote sensing and GIS. International journal of Remote sensing, 26(13), 2831-2849 (2005)

21. V.A. Tsihrintzis, dan R. Hamid. Runoff quality prediction from small urban catchments using SWMM. Hydrological Processes, 12(2), 311-329 (1998)

22. H. Huan, J. Wang, dan Y. Teng. Assessment and validation of groundwater vulnerability to nitrate based on a modified DRASTIC model: a case study in Jilin City of northeast China. Science of the total environment, 440, 14-23 (2012) 
23. M. Hürlimann, R. Copons, dan J. Altimir. Detailed debris flow hazard assessment in Andorra: a multidisciplinary apprgach. Geomorphology, 78(3-4), 359-372 (2006)

24. K. Papadopoulou-Vry Aoti, G.D. Bathrellos, H.D. Skilodimou, G. Kaviris, dan K. Makropoulos. Karst collapse susceptibil y apping considering peak ground acceleration in a rapidly growing urban area. Engineering Geolos $y, 158,77-88$ (2013)

25. B.I. Istijono, dan B.I. Hak am Development of Stability Criteria for Risk Reduction in The Sianok Canyon in Bukittinggi Indonesia. Intornational Journal of Earth Sciences anda Engineering (2016)

26. S. Suhari, dan M. Siebenhüner. nv renmental geology for land use and regional planning in the Bandung Basin, West Java, In onesi . Joyrnal of Southeast Asian Earth Sciences, 8(1-4), 557-566 (1993) 